\title{
Activation of the electroencephalogram with intravenous Brietal (methohexitone): the findings in 100 cases
}

\author{
JOHN GUMPERT AND RONALD PAUL \\ From the Department of Applied Electrophysiology, The National Hospital for Nervous Diseases, \\ Queen Square, London, and the Department of Neurology, The United Sheffield Hospitals
}

SUMMARY One hundred cases of methohexitone activation of the EEG are reported. The technique $\vec{\circ}$ seems to be especially valuable in the investigation of petit mal and temporal lobe epilepsy and adds valuable negative evidence in cases of suspected behaviour disorders.

The use of chemical agents as a method of activation of the electroencephalogram (EEG) has been a wellrecognized practice for over 30 years. The analeptics and induced sleep have been used, but with only limited success. The use of analeptic agents today is, in fact, much less widespread than hitherto. The main criticisms of such drugs have been their liability to induce seizures in normal individuals and their lack of reliability in inducing episodes in such patients who, on clinical grounds alone, would seem to have epilepsy. In this paper we present evidence to suggest that methohexitone (Brietal, Brevital) avoids these criticisms and appears to be a highly safe and effective activating agent.

Methohexitone is an 'ultra-short' acting intravenous agent. It now enjoys widespread use as an anaesthetic agent for induction and can be used in repeated doses for more prolonged periods of anaesthesia. Wyant and Change (1959) and Dundee and Moore (1961) have stressed the very rapid recovery from 'hangover' effects after its use. Both groups of authors mention the abnormal muscle movements and hiccups often associated with the use of the drug. Riffin (1960), using a single channel bipolar EEG monitor while giving the drug, reported the appearance of 2 to $6 \mathrm{~Hz}$ waves of moderate voltage and a return to the pre-injection EEG pattern in two and a half to five minutes. Fibrillary movements of the face and lips were noted in several of his patients. He pointed out that methohexitone differed from earlier short-acting barbiturates in having no sulphur atom at the $\mathrm{C} 2$ position and a methyl group at the N1 position (see Fig.). So far no reports of seizures induced in normal people by

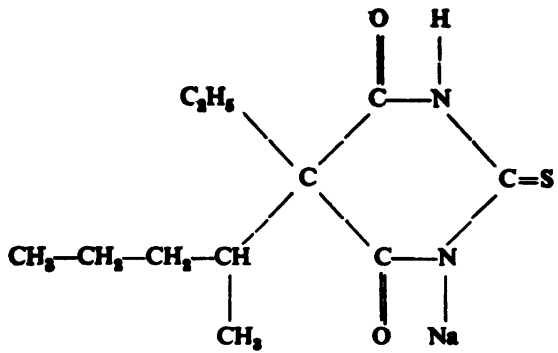

Sodium 5-ethyl-5 (1-methyl-butyl) - thiobarbiturate THIOPENTONE

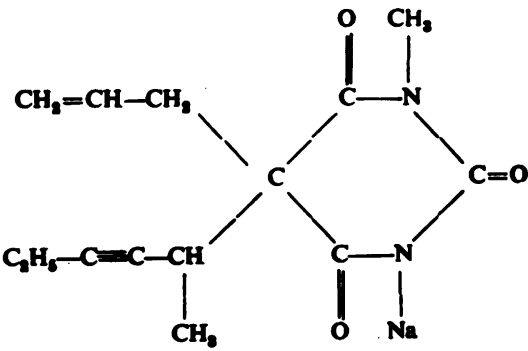

Sodium dl - 1 - methyl - S(allyl) - S(methyl-2-pentynyl) - barbiturate

\section{METHOHEXITONE}

FIG. Shows the formulae of thiopentone and methohexitone. 
this drug have appeared in the literature, and we felt it unjustifiable to give a general anaesthetic to a group of normal patients, however small the risk, especially as a control group of normal children had been studied by Goldie, Fried, Gould, and Pedersen (1968) and Riffin (1960) has reported the effects in adults.

Frank, Frazer, and Whitcher (1966) pointed out the sedative value of intramuscular methohexitone in hyperactive or hyperirritable children. They concluded that the EEG patterns obtained from these children resembled the changes produced in the EEG record when other sedatives were used. Goldie et al. (1968) described repeated small doses of intravenous methohexitone for calming subnormal and severely disturbed children. They noted no specific changes attributable to the methohexitone, but again felt that the drug was especially valuable in these patients. Paul and Harris (1970) compared the relative merits of methohexitone and thiopentone in facilitating abnormal spike discharges in the EEG. Gumpert, Hansotia, Paul, and Upton (1969) reported the remarkable ability of the drug to activate latent $3 / \mathrm{sec}$ spike-and-wave discharges in suspected petit mal epileptics in whom routine procedures had failed. They mentioned the small amount needed to produce this effect; further cases of this type are included in this paper.

Twenty-five cases in which 'centrencephalic-like' discharges were induced by Brietal were described by Wilder, Musella, van Horn, and Schmidt (1969). These were out of 27 examples which had shown similar previous abnormality. They confirmed the small doses needed to facilitate the discharges.

\section{METHODS}

The last consecutive 100 patients referred to the Departments of Applied Electrophysiology of the National Hospital, Queen Square, and to the United Sheffield Hospitals for activation EEGs are considered in this study. In each centre the recordings were carried out with a 16-channel Mingograph apparatus. The electrode placements were according to the International $10-20$ system. Base line records included at least three minutes of hyperventilation and a period of photic stimulation, and were bipolar with a time constant of $0.3 \mathrm{sec}$ and a high frequency cut of $30 \%$ at $70 \mathrm{~Hz}$. The particular montage used during activation was determined by the clinical history and the previous EEG record. A $1 \%$ solution of methohexitone was given by intravenous injection at a rate of $10 \mathrm{mg} / 20$ sec. The total dose given in those cases which resulted in additional information only exceeded $40 \mathrm{mg}$ in one case. The average adult sleep dose is said to be $70 \mathrm{mg}$.

\section{RESULTS}

The results of this study are presented in Tables 1 and
2. Table 1 enumerates those conditions in which methohexitone provides significant further positive or negative information. Table 2 lists those conditions in which methohexitone was of doubtful or limited value. The cases were classified into the various groups shown in the Tables on the basis of the referring physician's diagnosis and before any EEG studies, the classification being, therefore, carried out on clinical grounds alone. In those cases where methohexitone activation added no significant additional information, the effect of the drug on the EEG record was merely to show the usual appearance of a non-specific increase in slow activity intermixed with fast wave activity which then quickly cleared.

The ability of this drug to induce $3 / \mathrm{sec}$ spike-andwave discharges was seen in six out of seven $(86 \%)$ cases in which previous EEG recordings had been unhelpful. It is usually held that this type of activity can be demonstrated in most records with the help of hyperventilation.

In temporal lobe epilepsy the procedure was

\section{TABLE 1}

EFFECTS OF METHOHEXITONE ON EEG RECORD: CONDITIONS IN WHICH IT GIVES SIGNIFICANT ADDITIONAL INFORMATION

\begin{tabular}{lccccc}
\hline $\begin{array}{c}\text { Referring } \\
\text { physician's } \\
\text { diagnosis }\end{array}$ & $\begin{array}{c}\text { Normal } \\
\text { before: no } \\
\text { change }\end{array}$ & $\begin{array}{c}\text { Normal } \\
\text { before: } \\
\text { abnormal } \\
\text { after }\end{array}$ & $\begin{array}{c}\text { Abnormal } \\
\text { before: } \\
\text { no change }\end{array}$ & $\begin{array}{c}\text { Abnormal } \\
\text { before: } \\
\text { more } \\
\text { abnormal } \\
\text { after }\end{array}$ & Total \\
\hline $\begin{array}{l}\text { Petit mal 3/sec } \\
\text { spike and } \\
\text { wave }\end{array}$ & 0 & 6 & 0 & 1 & 7 \\
$\begin{array}{l}\text { Temporal lobe } \\
\text { epilepsy } \\
\begin{array}{l}\text { Behaviour } \\
\text { disorders }\end{array}\end{array} \quad 15$ & 4 & 0 & 7 & 15 & 31 \\
\hline
\end{tabular}

TABLE 2

EFFECT OF METHOHEXITONE ON EEG RECORD WHERE NO FURTHER SIGNIFICANT INFORMATION WAS OBTAINED

\begin{tabular}{lccccc}
\hline $\begin{array}{c}\text { Referring } \\
\text { physician's } \\
\text { diagnosis }\end{array}$ & $\begin{array}{c}\text { Normal } \\
\text { before: } \\
\text { no change }\end{array}$ & $\begin{array}{c}\text { Normal } \\
\text { before: } \\
\text { abnormal } \\
\text { after }\end{array}$ & $\begin{array}{c}\text { Abnormal } \\
\text { before: } \\
\text { no change }\end{array}$ & $\begin{array}{c}\text { Abnormal } \\
\text { before: } \\
\text { more } \\
\text { abnormal } \\
\text { after }\end{array}$ & Total \\
\hline $\begin{array}{l}\text { Grand mal } \\
\text { Minor epilepsy } \\
\text { other than }\end{array}$ & 2 & 1 & 8 & 6 & 17 \\
$\begin{array}{l}\text { 3/sec spike } \\
\text { and wave }\end{array}$ & 2 & 0 & 2 & 1 & 5 \\
$\begin{array}{l}\text { Other focal } \\
\text { epilepsy }\end{array}$ & 1 & 0 & 3 & 3 & 7 \\
$\begin{array}{l}\text { Other } \\
\text { diagnoses }\end{array}$ & 3 & 0 & 1 & 0 & 4 \\
Unknown & 8 & 0 & 4 & 0 & 12 \\
\hline
\end{tabular}


effective in demonstrating temporal lobe spike discharges in $12.9 \%$ of suspected cases where no previous EEG abnormality was noted. In temporal lobe epilepsy, $48.5 \%$ of cases which had shown previous EEG abnormalities had these accentuated by methohexitone. The changes seen in the cases of suspected temporal lobe epilepsy varied from unilateral theta activity (which then showed frank spike formation on injection) to unilateral focal discharges which on injection became bilateral.

Excluding the cases of temporal lobe epilepsy some of the other conditions listed showed an abnormal recording before the injection of methohexitone. However, this abnormality was not judged to be adequate either to confirm or to refute the clinical diagnosis. After injection sufficient additional information was elicited in the records to clarify the diagnosis.

\section{DISCUSSION}

This study suggests that the chief value of this technique lies in the investigation of suspected cases of petit mal, temporal lobe epilepsy, and behaviour disorders. Furthermore, since in some cases any one of these three possibilities may be suspected, it seems to represent a minor, but important diagnostic advance. The importance of being certain that a patient is, in fact, suffering from petit mal rather than temporal lobe epilepsy or some other form of minor epilepsy is appreciated clinically when considering treatment.

In our series the percentage of cases of temporal lobe epilepsy in which methohexitone evoked further EEG abnormalities is lower than that reported by Wilder (1969) and Musella, Wilder, and Schmidt (1969), but it should be noted that their diagnostic criteria were not identical. Wilder's group investi- $\underset{\mathbb{D}}{Z}$ gated suspected cases who on the EEG had already been shown to have a discharging focus in the temporal lobe.

Seventeen cases of 'behaviour disorder' were referred to us for further study and in no case did methohexitone reveal an EEG abnormality. The value of the drug in the EEG investigation of grand mal epilepsy appears to be limited in this study, but further work is at present being carried out to try to elucidate this point.

\section{REFERENCES}

Dundee, J. W., and Moore, J. (1961). Thiopentone and Methohexital. A comparison as main anaesthetic agents $\overrightarrow{\vec{c}}$ for a standard operation. Anaesthesia, 16, 50-60.

Frank, G. S., Fraser, R. A. R., and Whitcher, C. (1966). Intramuscular methohexital for rapid induction of short $\vec{\omega}$ duration sleep in the EEG Laboratory: a study of fortyfour hyperkinetic children. Electroenceph. clin. Neurophysiol., 21, 76-78.

Goldie, L., Fried, Y., Gould, T., and Pedersen, T. M. (1968). Electroencephalographs in the subnormal and the mentally ill child. Anaesthesia, 23, 364-371.

Gumpert, J., Hansotia, P., Paul, R., and Upton, A. (1969 Methohexitone and the E.E.G. Lancet, 2, 110.

Musella, L. Wilder, B. J., and Schmidt, R. P. (1969). EEQ 응 activation with intravenous Brevital in psychomot\& epilepsy. Neurology (Minneap.), 19, 278.

Paul, R., and Harris, R. (1970). A comparison of meth hexitone and thiopentone in electrocorticography. Neurol. Neurosurg. Psychiat., 33, 100-104.

Riffin, I. M. (1960). An appraisal of new induction agents J. med. Soc. N.J., 57, 15-19.

Wilder, B. J. (1969). Activation of epileptic foci in psychö motor epilepsy. Epilepsia, 10, 418.

Wilder, B. J., Musella, L., Van Horn, G., and Schmidt, R. P. (1969). Methohexital activation of 'centrencephalic-like' discharge. Electroenceph. clin. Neurophysiol., 27, 682.

Wyant, G. M., and Chang, C. A. (1959). Sodium metho- $\bar{\partial}$ hexital: a clinical study. Canad. Anaesth. Soc. J., 6, 40-50. 